UDC 34.342 .9

LBC 67.404

\title{
PROVISION OF PUBLIC AND MUNICIPAL SERVICES INVOLVING MINORS
}

\author{
Anastasiya G. Kolomeytseva \\ Volgograd Institute for the Humanities, Volgograd, Russian Federation
}

\begin{abstract}
Introduction: the institute of state and municipal services provision as one of the most important fields of the activity of the executive authorities and local governments needs to be improved, and one of its areas could become a more detailed scientific development and normative legal consolidation of the status of state and municipal service recipients. The aim of this study is to analyze the legislation regulating the provision of public and municipal services with the participation of minors in order to understand their specific legal status and filling gaps in its legal regulation. The methods of this study are the general scientific method of analysis, the system and structural method, as well as the formal and legal method. The result of this research is to expose the inadequacy in the legal regulation of the status of minors as the recipients of state and municipal services, the imperfection of the norms providing the ways of realizing their rights. Conclusions: for the purpose of improving the legal status of minors in the provision of public and municipal services it is necessary to make amendments to Federal Law № 210-FL for such a special category of service recipients as minors, and to consolidate their legal status fundamentals in this area.
\end{abstract}

Keywords: public and municipal services, minors, capacity, legal representatives, procedure for the provision of public and municipal services, administrative and legal status of minors.

УДК 34.342 .9

ББК 67.404

\section{ПРЕДОСТАВЛЕНИЕ ГОСУДАРСТВЕННЫХ И МУНИЦИПАЛЬНЫХ УСЛУГ С УЧАСТИЕМ НЕСОВЕРШЕННОЛЕТНИХ}

\author{
Анастасия Григорьевна Коломейцева \\ Волгоградский гуманитарный институт, г. Волгоград, Российская Федерация
}

\begin{abstract}
Введение: институт предоставления государственных и муниципальных услуг, как одна из наиважнейших сфер деятельности органов исполнительной власти и местного самоуправления, нуждается в совершенствовании, одними из направлений которого могут стать более детальная научная разработка и нормативноправовое закрепление статуса различных групп получателей государственных и муниципальных услуг. Целью данного исследования является проведение анализа законодательства, регламентирующего предоставление государственных и муниципальных услуг с участием несовершеннолетних, для уяснения специфики правового статуса последних и устранения пробелов в его нормативно-правовом регулировании. Методами данного исследования являются общенаучный метод анализа, системно-структурный метод, а также формально-юридический метод. Результатом исследования стало выявление недостаточности правового регу- лирования статуса несовершеннолетних как субъектов получения государственных и муниципальных услуг, 굴 несовершенства норм, закрепляющих способы реализации их субъективных прав в данной сфере. Выводы: в целях совершенствования правового положения несовершеннолетних в сфере предоставления государственных и муниципальных услуг необходимо внести изменения в Федеральный закон № 210-Ф3, касающиеся такой особой категории услугополучателей, как несовершеннолетние, и закрепить основы их правового статуса в данной области.

Ключевые слова: государственные и муниципальные услуги, несовершеннолетние, законные представители, дееспособность, порядок предоставления государственных и муниципальных услуг, административно-правовой статус несовершеннолетних.
\end{abstract}




\section{Введение}

Предоставление государственных и муниципальных услуг является одной из важнейших функций органов исполнительной власти и местного самоуправления, позволяющей дать объективную оценку деятельности данных органов со стороны гражданского общества и определить их значимость в осуществлении функций государства. Одной из наиболее злободневных тем проводимой в настоящее время административной реформы является вопрос об обеспечении доступности услуг, оказываемых государственными и муниципальными органами власти [5, с. 28]. Также среди приоритетных направлений совершенствования организации предоставления государственных и муниципальных услуг представители государственной власти и юридической науки называют повышение их качества, совершенствование порядка предоставления, но не менее важной и требующей правового закрепления категорией является статус услугополучателей. Научное обоснование, совершенствование и юридическое закрепление совокупности субъективных прав и обязанностей получателей государственных и муниципальных услуг позволили бы сделать значительный шаг на пути повышения эффективности предоставления государственных и муниципальных услуг.

\section{Правовой статус несовершеннолетних как субъектов предоставления государственных и муниципальных услуг}

В соответствии с п. 3 ст. 2 Федерального закона № 210-Ф3 заявителями, то есть субъектами, имеющими право обратиться за предоставлением государственных и муниципальных услуг, могут быть физические или юридические лица (за исключением государственных органов и их территориальных органов, органов государственных внебюджетных фондов и их территориальных органов, органов местного самоуправления) либо их уполномоченные представители [8]. Независимо от категории заявителя он должен соответствовать общим требованиям, установленным законодательством, то есть правоспособностью и дееспособностью. По мнению ав- торов комментария к ФЗ № 210 [3], физические лица как получатели государственных и муниципальных услуг должны обладать гражданской право- и дееспособностью. Применительно к физическим лицам общие правила устанавливают полную дееспособность по достижении гражданином 18 лет, однако в ряде случаев закон предусматривает и возможность наступления дееспособности в полном объеме до достижения указанного возраста. В данном случае закон наделяет такого гражданина всеми правами и обязанностями, установленными действующим законодательством, что предполагает и предоставление им возможности обращения за предоставлением государственных либо муниципальных услуг.

Однако представляется, что в случае предоставления государственных и муниципальных услуг нормы гражданского законодательства применимы не всегда. Поскольку заявитель взаимодействует с органами государственной власти и местного самоуправления, при этом общей целью этого взаимодействия является достижение неких публичных интересов, соответствующие отношения регулируются нормами административного права, и физические лица, обращающиеся за предоставлением государственных и муниципальных услуг, должны обладать прежде всего административной правосубъектностью. Как юридическая категория, административная правосубъектность складывается из административной правоспособности, административной дееспособности и административной деликтоспособности. Административная правоспособность возникает с рождения, административная деликтоспособность возникает у физического лица по достижении возраста 16 лет. А вот момент возникновения административной дееспособности является весьма проблематичным, поскольку определенные права и обязанности у физического лица в публичных правоотношениях возникают до совершеннолетия, то есть до возраста полной дееспособности. По мнению О.В. Купцовой, правосубъектность несовершеннолетнего определяется его правоспособностью и дееспособностью (включая деликтоспособность), выступает необходимой предпосылкой субъективных прав и обязанностей ребенка. Дееспособность несовершеннолетнего в силу 
возрастных особенностей неполна и компенсируется дееспособностью взрослых (законных представителей) [4, с. 198].

Анализ законодательства о государственных и муниципальных услугах позволяет выявить тот факт, что в процессе их предоставления нередко самостоятельно участвуют несовершеннолетние лица, причем их статус (включающий и правосубъектность) изменяется в зависимости от их возраста, вида предоставляемой услуги, объекта соответствующих правовых отношений, сферы этих отношений и статуса иных участников данных отношений. Например, Т.А. Смагина предлагает классифицировать административно-правовой статус несовершеннолетнего по двум основаниям: в зависимости от субъективных и объективных факторов, определяющих поведение несовершеннолетнего и возможности получения и использования им конкретных прав и обязанностей, и в зависимости от определенных прав и законных интересов в социальной сфере, которые несовершеннолетний может реализовывать [7, с. 62]. Подобная ситуация не позволяет говорить о необходимости принятия какоголибо специального закона, регламентирующего административно-правовой статус несовершеннолетнего. Однако в сфере предоставления государственных и муниципальных услуг в случае, когда несовершеннолетний может выступать как самостоятельный получатель услуг, необходимо установить пределы его дееспособности. Представляется, что если лицо, не достигшее возраста полной гражданской дееспособности, наделяется правом обращаться за предоставлением государственных или муниципальных услуг, то оно достигло достаточной физической и умственной зрелости для того, чтобы обладать полным комплексом прав, предусмотренных законом № 210-Ф3.

\section{Виды государственных}

\section{и муниципальных услуг, предоставляемых с участием несовершеннолетних}

В целом участие несовершеннолетних в предоставлении государственных и муниципальных услуг может выражаться в следующих формах:
1. В некоторых случаях отечественное законодательство прямо обязывает граждан РФ, в том числе несовершеннолетних, обратиться за предоставлением государственной услуги. Речь идет о получении паспорта гражданина РФ. Соответствующим Постановлением Правительства РФ установлено, что паспорт обязаны иметь все граждане Российской Федерации, достигшие 14-летнего возраста и проживающие на территории Российской Федерации. Таким образом, в качестве получателя государственной услуги выступает несовершеннолетний, который самостоятельно подает заявление и все необходимые документы и по смыслу ФЗ № 210 обладает всеми правами получателя государственных услуг: правом на получение услуги своевременно и в соответствии со стандартом; правом на получение полной, актуальной и достоверной информации о порядке предоставления государственных и муниципальных услуг; правом на получение государственных и муниципальных услуг в электронной форме, если это не запрещено законом; правом на получение государственных и муниципальных услуг в многофункциональном центре и правом на досудебное (внесудебное) рассмотрение жалоб в процессе получения государственных и (или) муниципальных услуг. Однако при этом несовершеннолетний получатель государственной услуги не обладает правом на самостоятельную судебную защиту своих нарушенных прав. Судопроизводство в данном случае будет вестись в соответствии с Кодексом административного судопроизводства РФ (далее - КАС РФ), а ч. 3 ст. 54 устанавливает, что права и законные интересы граждан, ограниченных в дееспособности, граждан, которые не достигли возраста восемнадцати лет, могут защищать в судебном процессе представители или законные представители родители, усыновители, попечители и иные лица, которым это право предоставлено федеральным законом [2]. При этом в КАС РФ отсутствует даже норма, включенная в Гражданский процессуальный кодекс, о том, что суд обязан привлекать к участию в деле самих несовершеннолетних. Таким образом, на несовершеннолетнего, как на дееспособного участника соответствующих правовых отношений, фактически возлагается обязанность 
обратиться за предоставлением государственной услуги, но в дальнейшем его административная дееспособность остается ограниченной. С другой стороны, исполнение данной обязанности не обеспечено никакими юридическими средствами. Статья 19.15 КоАП РФ за проживание гражданина РФ без удостоверения личности гражданина (паспорта) устанавливает административную ответственность, но поскольку административная деликтоспособность возникает с 16 лет, то несовершеннолетний, достигший четырнадцатилетнего возраста и не получивший паспорт гражданина РФ, не несет ответственности за уклонение от данной обязанности.

2. Участие несовершеннолетних в предоставлении государственных и муниципальных услуг может осуществляться по их добровольному выбору как самостоятельно, так и с участием их законных представителей. Так, например, Федеральным законом «О безопасности дорожного движения» право управления транспортными средствами категории «М» и подкатегории «А1» предоставляется лицам, достигшим шестнадцатилетнего возраста, не имеющим противопоказаний к управлению транспортными средствами и прошедшим профессиональное обучение. При этом ни в указанном законе, ни в Постановлении Правительства РФ «О допуске к управлению транспортными средствами», ни в Административном регламенте по предоставлению государственной услуги по проведению экзаменов на право управления транспортными средствами и выдаче водительских удостоверений Министерства внутренних дел Российской Федерации не имеется никаких специальных норм, регламентирующих статус несовершеннолетнего и закрепляющих его процессуальные права при предоставлении услуги.

Поскольку трудовое законодательство разрешает трудовую деятельность с 16, а в некоторых случаях - с 14 лет, несовершеннолетний вправе обратиться в органы занятости за предоставлением государственной услуги по организации его временного трудоустройства и зарегистрироваться в целях поиска подходящей работы. Предоставление такой государственной услуги предусмотрено, например, приказом Министерства труда и занятости населения Волгоградской области от 29 ноября 2013 г. № 327-д, при этом в качестве заявителя прямо указывается несовершеннолетний в возрасте от 14 до 18 лет.

Также несовершеннолетний обладает правом получения загранпаспорта как в случае выезда из Российской Федерации со своими родителями или иными законными представителями, так и в случае самостоятельного выезда. Несовершеннолетние, так же как их законные представители, могут выступать в качестве заявителей при предоставлении государственной услуги по выдаче предварительного разрешения на вступление в брак несовершеннолетним гражданам, достигшим 16-летнего возраста и т. д.

3. Третью группу представляют собой государственные и муниципальные услуги, предоставляемые, собственно, без участия несовершеннолетних, но предполагающие осуществление неких дополнительных процедур в интересах несовершеннолетних либо напрямую затрагивающие интересы несовершеннолетних. При этом законный интерес несовершеннолетнего следует рассматривать как объективно обусловленный юридически установленный предел для родителей и заменяющих их лиц (законных представителей) с целью достижения наилучшего результата в обеспечении разнообразных потребностей несовершеннолетнего, охраняемый и защищенный на основании закона уполномоченными субъектами [6, с. 101-102]. К таким отношениям можно отнести государственную регистрацию сделок с недвижимостью, имеющих обременения, где несовершеннолетнему может принадлежать доля имущества, собственно, услуги по выдаче разрешения на совершение сделок с имуществом несовершеннолетних, распоряжению средствами материнского капитала и другие.

\section{Выводы}

В свете изложенного выше представляется, что разобщенность российского законодательства, регулирующего правовой статус несовершеннолетних, оказывает негативное влияние на уровень и степень их правовой защищенности, ответственности. Особенно это касается административного законодатель- 
ства. Поскольку несовершеннолетние наравне с полностью дееспособными лицами, достигшими возраста 18 лет, участвуют во взаимодействии с публичными институтами в сфере предоставления государственных и муниципальных услуг, следует на нормативном уровне более детально регламентировать их административно-правовой статус, что позволит на высоком уровне обеспечить защиту их прав, ведь даже в советском законодательстве «защита прав детей была связана прежде всего с отраслевой институализацией, и защита интересов ребенка осуществлялась по отраслевому признаку» $[1$, с. 89]. Соответственно необходимо внести изменения в Федеральный закон «Об организации предоставления государственных и муниципальных услуг», касающиеся категорий заявителей, и установить, что к заявителям относятся, в том числе, несовершеннолетние в возрасте от 14 до 18 лет, а также закрепить основы их административно-правового статуса в данной сфере, определить, в каких случаях несовершеннолетний вправе самостоятельно обращаться за предоставлением государственной либо муниципальной услуги и какие правовые последствия это повлечет, в каких случаях за предоставлением государственной услуги, субъектом которой будет несовершеннолетний, могут обращаться его законные представители.

\section{СПИСОК ЛИТЕРАТУРЫ}

1. Бондаренко, О. А. Права и свободы ребенка в конституционном законодательстве Советского государства / О. А. Бондаренко // Вестник Волгоградского государственного университета. Серия 5 , Юриспруденция. - 2016. - № 2 (31). - С. 88-92.

2. Кодекс административного судопроизводства Российской Федерации от 8 марта 2015 г. № 21Ф3 // Собрание законодательства РФ. - 2015. № 10. - Ст. 1391.

3. Комментарий к Федеральному закону «Об организации предоставления государственных и муниципальных услуг» (постатейный) от 27 июля 2010 г. №210-Ф3/ Р. В. Амелин, Е. С. Ведяева, А. М. Викулов [и др.]. - Подгот. для системы «КонсультантПлюс», 2014.

4. Купцова, О. В. Теоретико-правовые аспекты правосубъектности несовершеннолетнего / О.В.Купцова // Глобальный научный потенциал. - 2015. - № 11 (56). - С. 197-199.
5. Мамай, Е. А. Публичные услуги и электронное правительство в современных государствах: точки соприкосновения и направления развития / Е. А. Мамай // Вестник Волгоградского государственного университета. Серия 5, Юриспруденция. -2013 . - № 2 (19). - С. 28-33.

6. Покачалова, Е. В. Законные интересы несовершеннолетних как объект административно-правового регулирования / Е. В. Покачалова, Т. А. Смагина // Вестник Саратовской государственной юридической академии. - 2012. - № 85. - С. 98-102.

7. Смагина, Т. А. Административно-правовой статус несовершеннолетнего как объект (предмет) / Т. А. Смагина // Вестник Саратовской государственной юридической академии. - 2013. - № 6 (95). C. 61-66.

8. Федеральный закон «Об организации предоставления государственных и муниципальных услуг» от 27 июля 2010 г. № 210-Ф3 // Собрание законодательства РФ. - 2010. - № 31. - Ст. 4179.

\section{REFERENCES}

1. Bondarenko O.A. Prava i svobody rebenka v konstitutsionnom zakonodatelstve Sovetskogo gosudarstva [Rights and Freedoms of the Child in the Constitutional Legislation of the Soviet States]. Vestnik Volgogradskogo gosudarstvennogo universiteta. Seriya 5, Yurisprudentsiya [Science Journal of Volgograd State University. Jurisprudence], 2016, no. 2 (31), pp. 88-92.

2. Kodeks administrativnogo sudoproizvodstva Rossiyskoy Federatsii ot 08.03.2015 № 21-FZ [Code of Administrative Procedure of the Russian Federation of March 8, 2015 no. 21-FL]. Sobranie zakonodatelstva $R F, 2015$, no. 10, art. 1391.

3. Amelin R.V., Vedyaeva E.S., Vikulov A.M., et al. Kommentariy $k$ Federalnomu zakonu ot 27.07.2010 № 210-FZ «Ob organizatsii predostavleniya gosudarstvennykh i munitsipalnykh uslug» (postateynyy) [The Commentary to the Federal Law of July 27, 2010 № 210-FZ "On Organization of the Provision of Public and Municipal Services" (Itemized)]. Prepared for "KonsultantPlyus" system, 2014.

4. Kuptsova O.V. Teoretiko-pravovye aspekty pravosubyektnosti nesovershennoletnego [Theoretical and Legal Aspects of the Legal Personality of Minors]. Globalnyy nauchnyy potentsial, 2015, no. 11 (56), pp. 197-199.

5. Mamay E.A. Publichnye uslugi i elektronnoe pravitelstvo v sovremennykh gosudarstvakh: tochki soprikosnoveniya i napravleniya razvitiya [Public Services and the Electronic Government in Modern States: Things in Common and Development 
А.Г. Коломейщева. Предоставление государственных и муниципальных услуг с участием несовершеннолетних

Directions]. Vestnik Volgogradskogo gosudarstvennogo universiteta. Seriya 5. Yurisprudentsiya [Science Journal of Volgograd State University. Jurisprudence], 2013, no. 2 (19), pp. 28-33.

6. Pokachalova E.V., Smagina T.A. Zakonnye interesy nesovershennoletnikh kak obyekt administrativno-pravovogo regulirovaniya [The Legitimate Interests of the Minors as an Object of Administrative-Legal Regulation]. Vestnik Saratovskoy gosudarstvennoy yuridicheskoy akademii, 2012, no. 85, pp. 98-102.
7. Smagina T.A. Administrativno-pravovoy status nesovershennoletnego kak obyekt (predmet) [Administrative and Legal Status of a Minor as an Object (Subject)]. Vestnik Saratovskoy gosudarstvennoy yuridicheskoy akademii, 2013, no. 6 (95), pp. 61-66.

8. Federalnyy zakon «Ob organizatsii predostavleniya gosudarstvennykh i munitsipalnykh uslug» ot 27.07.2010 № 210-FZ [Federal Law “On Organization of the Provision of Public and Municipal Services" of July 27, 2010]. Sobranie zakonodatelstva Rossiyskoy Federatsii, 2010, no. 31, art. 4179.

\section{Information About the Author}

Anastasiya G. Kolomeytseva, Senior Lector, the Department of State and Legal Disciplines, Volgograd Institute for the Humanities, Gribanova St., 12, 400011 Volgograd, Russian Federation, gou_anastasia@mail.ru.

\section{Информация об авторе}

Анастасия Григорьевна Коломейцева, старший преподаватель кафедры государственно-правовых дисциплин, Волгоградский гуманитарный институт, ул. Грибанова, 12, 400011 г. Волгоград, Российская Федерация, gou_anastasia@mail.ru. 